\title{
ピッチ一アントラキノン縮合物の熱的挙動
}

山田能生, 関根勇一*, 古田 毅, 白石 稔, 吉富末彦*

(平成 3 年 3 月 27 日受理)

\section{Thermal Behaviors of Pitch-Anthraquinone Condensates}

\author{
Yoshio Yamada, Yuichi Sekine*, Takeshi Furuta, Minoru Shiraishi \\ and Suehiko Yoshitomi*
}

\begin{abstract}
National Research Institute for Pollution and Resources
Onogawa 16-3, Tsukuba-shi, Ibaraki 305, Japan

* Shibaura Institute of Technology

9-14, Shibaura 3-chome, Minato-ku, Tokyo 108, Japan
\end{abstract}

Pitch (CTP)-anthraquinone (AQ) and hydrogenated pitch (HCTP)-AQ condensates were prepared by reacting the pitch and AQ in the presence of polyphosphoric acid with various mixing ratios. The reaction mechanism of the pitch and AQ was investigated by use of some model compounds. These condensates obtained were characterized in terms of solubility for solvents, thermogravimetric analysis and observation of optical textures of the heat-treated products. The condensates prepared with a mixing ratio of $7 / 3-6 / 4$ for CTP to AQ gave a maximum carbonization yield $(76 \%)$ at $1000^{\circ} \mathrm{C}$ and the carbonized products showed a mozaic texture. In the case of HCTP-AQ, a comparable high yield and a similar texture were obtained for the condensate prepared with an equal amount of HCTP and AQ. It was found that the hydrogenation of pitch to be condensated with AQ is important to improve the solubilization of the condensates for solvents and also to develop the anisotropic textures. Both condensates with the high carbonization yield gave a large interlayer spacing of about $0.34 \mathrm{~nm}$ on the heat-treatment up to $2200^{\circ} \mathrm{C}$, but the graphitizability was considerably enhanced when they were heat-treated above $2500^{\circ} \mathrm{C}$.

KEYWORDS: Pitch-anthraquinone condensates, Polyphosphoric acid, Carbonization, Optical texture, Graphitization

\section{1. 緒言}

ポリリン酸の脱水縮合反応を利用して種々の高分子化

公害資源研究所: $\mathbf{7} 305$ 茨城県つくば市小野川16-3

*芝浦工業大学 : 7108 東京都港区芝浦 3 丁目 9-14
合物が合成できるてとはよく知られている11。著者らは ポリリン酸を用いてアントラセンの重合物を合成し, 生 成物の構造や炭素化，黒鉛化挙動を調べた ${ }^{2)}$ 。その結果， この重合物は比較的重合度が低いにもかかわらず, 炭素 化収率は高くなることが明らかとなった。

従来からピッチの改質や芳香族化合物の重縮合反応汇, 塩化アルミニウム ${ }^{3)}$, 溶融塩 ${ }^{4)}, \mathrm{HF} / \mathrm{BF}_{3}{ }^{5)}$, 硝酸 ${ }^{6)}$ なよ゙ 
Table 1 Elemental analyses of pitches.

\begin{tabular}{lccccc}
\hline \multicolumn{1}{c}{ Pitch } & $\mathrm{C}$ & $\mathrm{H}$ & $\mathrm{O}$ & $\mathrm{N}_{\text {dif. }}$ & $\mathrm{C} / \mathrm{H}$ \\
\hline CTP & 93.2 & 5.1 & 1.3 & 0.4 & 1.54 \\
HCTP & 92.6 & 6.3 & 1.6 & - & 1.23 \\
\hline
\end{tabular}

が触媒として主に用いられてきている。著者らが報告し たポリリン酸を触媒とした反応がピッチなどに対しても 適用できれば，ピッチ類の新しい改質法之なるばかりで なく, 炭素材料のバインダーや炭素䋐維強化炭素複合材 料のマトリックスなどへの応用も期待される7)。また, ポリリン酸は反応後加水分解して, 容易化反応物から分 離することができるうえに, リン酸は不揮発性であるた め加熱, 脱水することによりある程度回収可能であると いう利点むある。

本研究ではポリリン酸を触媒としたアントラキノンと ピッチならびに水素化ピッチとの反応を試みた。乙こで は, ピッチとアントラキノンとの比率を種々変化させて 合成した生成物の溶剂位対する溶解性や炭素化の挙動, 炭素化物の組織などを調べた。さらに，2，3のモデル 化合物を用いてアントラキノンとの縮合化の反応過程を より詳細に調べた。

\section{2. 実験}

\section{1 試料とその調製}

使用したピッチは, 川崎製鉄(株)製の軟化点約 $90^{\circ} \mathrm{C}$ (QIフリー)のコールタールピッチ (CTP) である。水 素化コールタールピッチ (HCTP) は, テトラリンノアン トラセン油の $1: 1$ 混合溶媒中, 脱硫触媒を用いて水素 化処理した後, $6.7 \times 10^{2} \mathrm{~Pa}$ の減圧下 $300^{\circ} \mathrm{C}$ で軽質分を 除いて調製した。CTP と HCTPの元素分析值を Table 1 亿示す。炭素と水素は柳本商事(株)製 Yanaco MT3 型 CHN コーダーで, また酸素は三田村理研工業(株) 製酸素微量定量分析装置 (1-90)を用い, 電量滴定法で 分析した。ピッチをポリリン酸に加え, ピッチに対して 種々の重量比でアントラキノン (AQ) を添加して窒素 気流中, $140^{\circ} \mathrm{C}$ で 5 時間反応させた。反応後水を加えて ポリリン酸をリン酸として濾過, 除去し, 不溶分を $5 \%$ のアンモニア水溶液, さらに水で十分に洗浄した。その 後, メタノールによるソックスレー抽出で未反応物を除 き, 抽出残渣を $130^{\circ} \mathrm{C}$ で真空乾燥して生成物を得た。 仕込九だ反応物の総量に対する生成物の収量を収率とし て求めた。添加したアントラキノンの割合が 0 から $30 \%$ までは, 生成物の収率は約 $95 \%$ とほぼ一定であるが, 40 , 50\%と増加するにつれて $91,83 \%$ と低下した。
モデル化合物としては, 東京化成(株)のナフタレン, 1,4 -ジヒドロナフタレン, $\alpha-x$ チルナフタレン, $\beta$-メチ ルナフタレンの特級試薬をそのまま用いた。

\section{2 生成物の溶剂抽出}

生成物のアセトン, トルエン, ピリジンに対する溶解 度は, ソックスレー抽出器を用いて溶剤の沸点で抽出し, 不溶分量から求めた。

\section{3 熱重量測定亡熱処理}

熱重量測定には, 理学電機(株) 製熱天秤8) を用いた。 約 $20 \mathrm{mg}$ を精秤した試料について, 窒素流通下, $1000^{\circ} \mathrm{C}$ までの重量変化から減量曲線を求めた。また, 顕微鏡観 察に用いた試料は, 各縮合物をパイレックスガラス管に 入れ, 流動砂浴中で窒素ガスを流しながら $440^{\circ} \mathrm{C}$ で 5 時 間処理したあのである。

\section{4 マススペクトルおよびX 線回折の測定}

FDマススペクトルは日本電子(株)製 JMS-300型装置 を用い, テトラヒドロフランに溶かした試料を注射器で 試料室に導入して観測した。X 線回折は前報 ${ }^{2)}$ と同様, 学振法に準拠して測定した。

\section{3. 結果と考察}

\section{1 生成物の溶解度}

反応開始時に CTP または HCTP と AQ の混合比を 種々変えて合成した生成物のアセトン, トルエン, ピリ ジン不溶分量を Fig. 1 および 2 亿示す。ててで $\mathrm{AQ} の$ 割合が多くなると $\mathrm{AQ}$ が未反応として残り,ての $\mathrm{AQ}$ は 反応後メタノール抽出等で除去されるので, 実際の生成 物中には必ずし屯仕込時と同じ比率の $\mathrm{AQ}$ が含まれて いるとは限らないととに注意する必要がある。事実 2.1 で述べたように，ピッチに対する $\mathrm{AQ} の$ 比率が高くな るにつれて生成物の収率が低下してくる。てれらの図か ら、いずれの溶媒を用いても同じような傾向を示してい るととがわかる。すなわち, CTP系ではピッチの割合 が低下するにつれて不溶分量が增大し, C T P L A Q を 6/4の重量比で反応させた場合に最大となった。乙のと きの生成物のピリジン不溶分は約 $38 \%$ であった。

一方, HCTP系では AQの仕込比が30\%まではわず かな增加に留まっているが, それ以上になると急激に増 加する。HCTP 中には水素添加によってナフテン環10) 


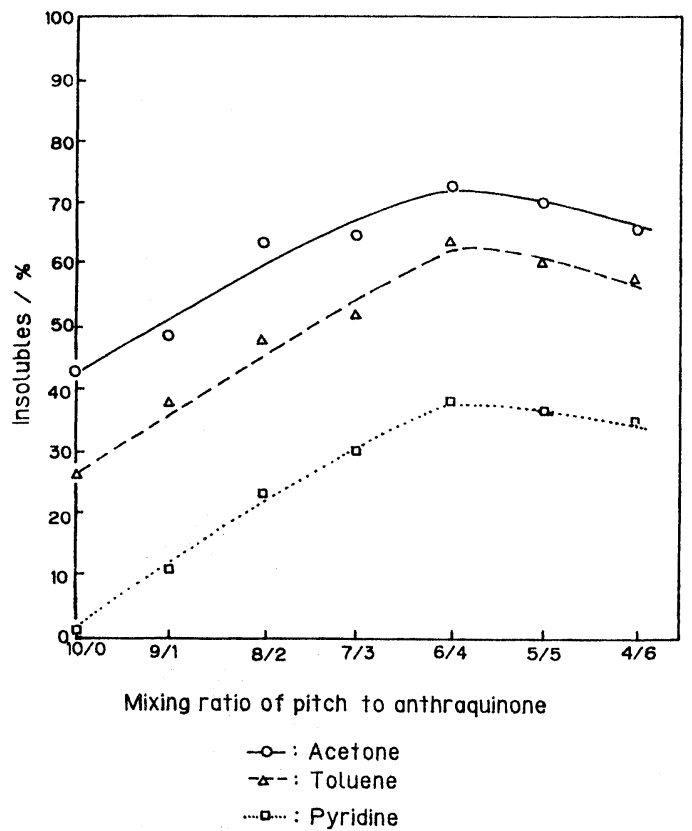

Fig. 1 Change in amount of insolubles of condensates with mixing ratio of CTP to anthraquinone.

やナフテン環の分解により生成したアルキル側銷などが 存在していると考えられる。後述するモデル化合物の実 験からも予想されるように, AQ の仕込比が少ない段階 では,ナフテン環などをあつ分子が優先的に $\mathrm{AQ}$ 之縮 合物を形成し，て机らは比較的水素を多く含んでいるた め, 溶剤飞溶けやすいと推定される。しかし，AQ の添 加量が多くなると CTP 系と同様化，ナフテン環以外の 化合物とあ反応してくるため, その縮合物は溶剤に不溶 化すると思われる。

$\mathrm{AQ}$ がピッチと縮合化反応を起てす場合，ピッチとの 反応関与しない $\mathrm{AQ}$ は生成物の後処理で除去される。 そのため, AQ の添加量がある值を越えるとほぼ同程度 の分子量をむつ縮合物が形成されていると考えられ, Fig. 1 や Fig. 2 の溶剂不溶分量は一定の值をとるはず である。HCTP系ではこのような傾向が見られるが， CTP 系では AQ が増加するにつれて不溶分量がわずか 亿低下している。乙の原因については明らかではない。 以上の結果から, CTP 系の場合には AQ の添加量が増 加するにつれて溶剤不溶分量も増加するが, HCTP 系 の場合には $\mathrm{AQ}$ 添加量が少ない段階では HCTP 中のナ フテン環やアルキル側鎖をむつ化合物が $\mathrm{AQ}$ 之縮合物を 形成してあ, 溶剂化対する溶解度はあまり变化しないて

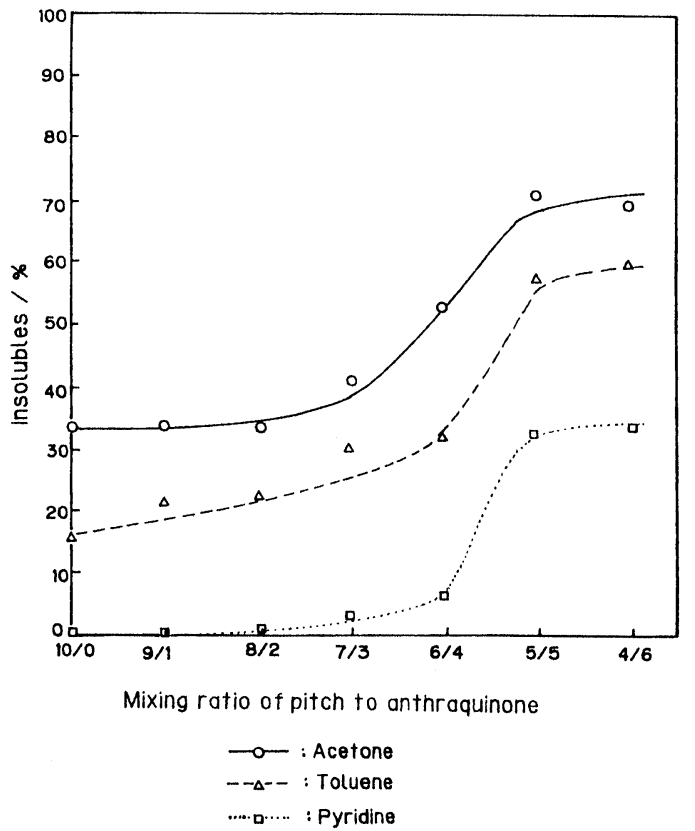

Fig. 2 Change in amount of insolubles of condensates with mixing ratio of HCTP to anthraquinone.

とがわかった。したがって，ピッチを予め水素化するて とによって溶剤不溶分の比較的少ない縮合物を調製する ことが可能である。

\section{2 モデル化合物による反応機構}

ピッチは芳香族環などを含む多数の複雑な分子の集合 体である。そてでアントラキノンの反応性をより詳細に 検討するため, ピッチ抢よび水素化したピッチのモデル 化合物としてナフタレン, 1, 4- ジヒドロナフタレン $(\mathrm{DHN}), \alpha$-メチルナフタレン (AMN), $\beta$-メチルナフ タレン $(\mathrm{BMN})$ を選び, モル比で $1: 1$ の $\mathrm{AQ}$ と反応さ せ, 生成物の構造から反応機構の推定を試みた。生成物 の収率を Table 2 亿示す。DHN, AMN 抢よび BMN では収率が約70 80\%と非常に高く, AQ とは容易に反 応するてとがわかる。一方, ナフタレンでは $8.0 \%$ と非 常に低い。また, 比較のため $\mathrm{AQ}$ のみをポリリン酸中 で処理した場合には生成物はほとんど得られず，AQ だ けでは縮合反応は起とっていないてとがわかる。てれら の結果は, ナフテン環やアルキル側鎖をむった芳香族化 合物が $\mathrm{AQ}$ と反応しやすいてとを示唆している。

次に, 生成物の構造を FD マススペクトルによって調 べた（Fig.3)。DHN/AQから得られた生成物では， 質量数338のピークがかなり強く, 乙の質量数をもとに 
Table 2 Yield of condensates obtained from model compounds and anthraquinone (AQ) in polyphosphoric acid.

\begin{tabular}{cc}
\hline Model & Yield $(\%)$ \\
\hline Naphthalene & 8.0 \\
1, 4-Dihydronaphthalene & 76.7 \\
$\alpha$-methylnaphthalene & 68.0 \\
$\beta$-methylnaphthalene & 80.5 \\
AQ alone & 0.2 \\
\hline
\end{tabular}

(a) $D H N / A Q$
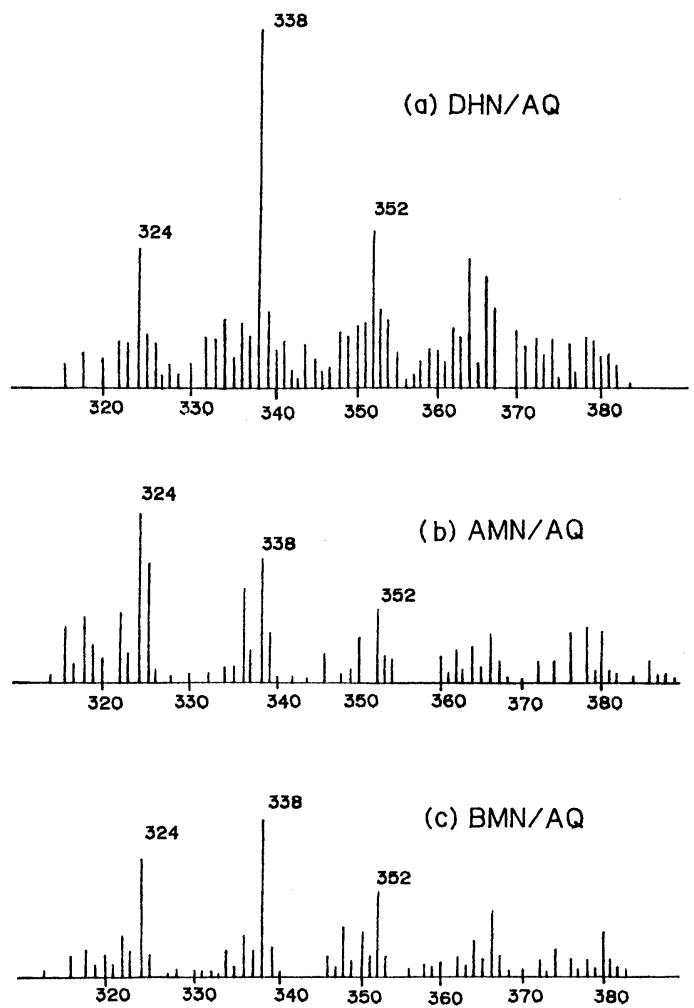

Fig. 3 FD mass spectra of condensates from (a) 1, 4-dihyronaphthalene (DHN/anthraquinone $(\mathrm{AQ})$, (b) $\alpha$-methylnaphthalene $(\mathrm{AMN}) / \mathrm{AQ}$ and (c) $\beta$-methylnaphthalene (BMN)/AQ

推定した反応機構を Fig.4 亿示す。まず AQ がポリリ ン酸と反応して Fig. 4 の(1)のようなカチオンを形成し, 乙れが DHN と反応して質量数338をもつ化合物が生成 するあのと推定される。他方, AMN や BMNでは質量

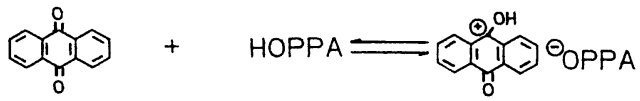

$A Q$

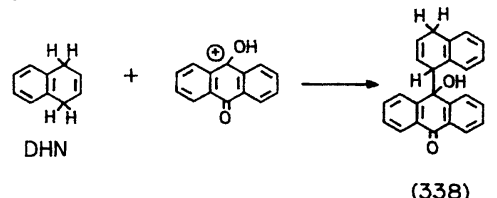

Fig. 4 Reaction scheme of anthraquinone (AQ) and 1, 4-dihyronaphthalene (DHN) in polyphosphoric acid (HOPPA).

数の異なるいくつかのピークが現れた（Fig. 3)。乙のう ち主要なピークとして質量数 $324,338,352$ をとに推定 した生成物の分子構造を Fig.5 亿示す。一般にルイス酸 などの強酸触媒を用いた芳香族化合物のイオン化反応で は，プロトン移動による不均化反応，アルキル基の移動 による異性化反応が容易に起こる ${ }^{11)}$ 。ポリリン酸中にお いてあ, プロトンやメチル基の移動による反応が考えら れることから,メチルナフタレンは一部ナフテン環構造 に変化しているあのと仮定した。てのように，ポリリン 酸中で $\mathrm{AQ}$ と反応した生成物は比較的水素を多く含ん でいる。てれは 3.1 で述べた水素化して反応性を高めた HCTP と AQ とから得られた縮合物が, $\mathrm{AQ}$ の添加量 が低い段階では比較的溶剂によく溶けるという実験事実 を裏付けている。

\section{3 縮合物の熱重量変化}

CTP-AQ の混合比が異なる縮合物について測定した 代表的な熱重量曲線を Fig. 6 亿示す。こてで例えば CTP-90 は仕込比で CTP とAQ の割合が $9 / 1$ であるて とを示している。したがって, CTP-100 は CTPのみを ポリリン酸中で処理したあのである。参考のために $\mathrm{AQ}$ のみの重量変化を調べたが, $200^{\circ} \mathrm{C}$ から昇華するため, 炭素化物は得られなかった。また, 原料 $\mathrm{CTP}$ は $1000^{\circ} \mathrm{C}$ 


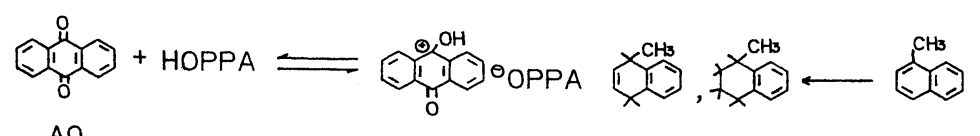

(1)

$A Q$

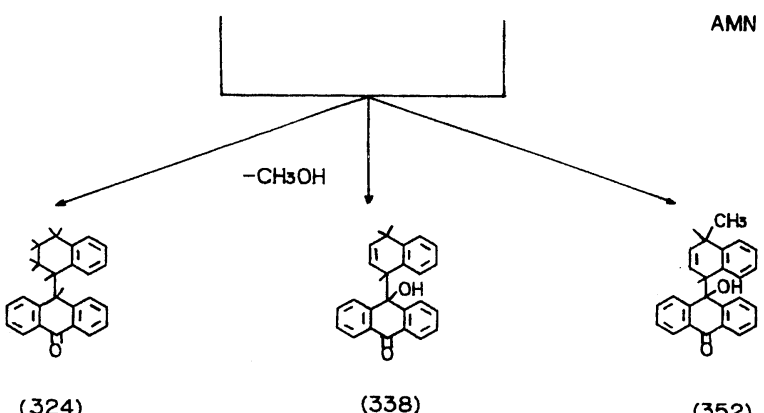

Fig. 5 Reaction scheme of anthraquinone (AQ) and Methylnaphthalene $(A M N)$ in polyphosphoric acid (HOPPA).

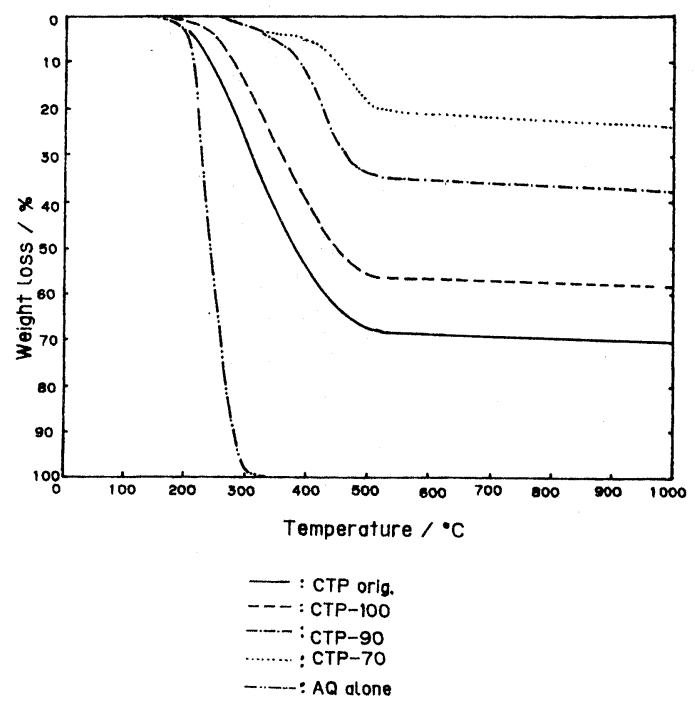

Fig. 6 Change in weight loss of CTP, CTP/ anthraquinone (AQ) and AQ with heattreatment temperature.

での収率が30\%であるのに対し，このピッチのみをポリ リン酸処理した CTP-100では, 収率が42\%と末処理の CTPより12\%む上昇した。乙れは前述したように，ピ ッチ中の分子同志で縮合反応が起てっているととを示唆 しているが, 同時に CTP 中の軽質分が抽出操作などの 処理で一部除かれ，見かけ上重質化したのかむしれない。

この図からいずれの試料も重量減少は主として 250〜 $500^{\circ} \mathrm{C}$ で起とっており, ピッチの仕込比が少ない縮合物 ほど炭素化収率が高くなる。1000ㄷ での炭素化収率を

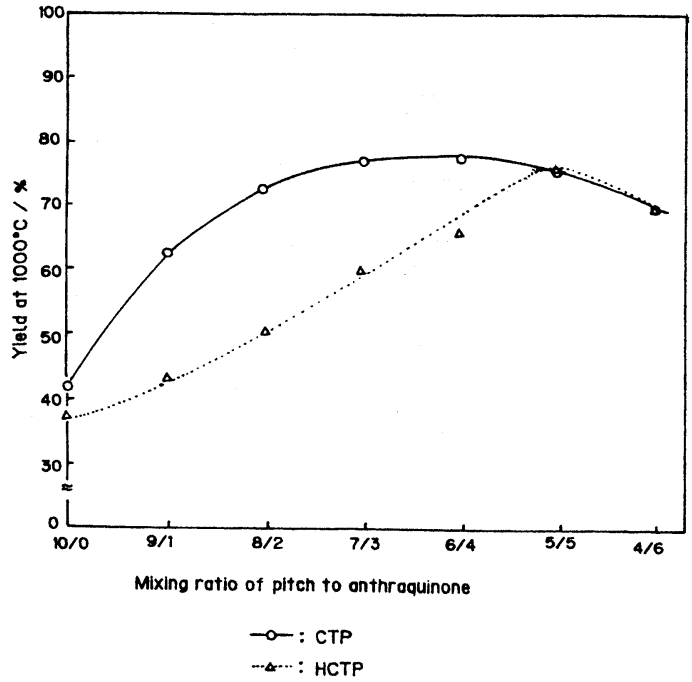

Fig. 7 Relation between yield at $1000^{\circ} \mathrm{C}$ and mixing ratio of pitch to anthraquinone.

CTPあるいはHCTP と AQ の仕込比に対してプロッ トした図が Fig.7である。CTP系では, $\mathrm{AQ}$ との仕込 比 7/3 から 6/4の間で最高の収率 $(76 \%)$ 亿達している のに対し, HCTP 系ではピッチの添加量が減少するに つれて徐々に増加し, $\mathrm{AQ}$ との仕込比 5/5 でCTP 系の 最高の収率に匹敵する77\%の収率になった。前述のよう に, CTP系では AQ が主として側鎖をむった芳香族化 合物と反応するのに対し, HCTP系ではてのような反 応に加えてナフテン環とも脱水縮合反応を起てすため, より多くの $\mathrm{AQ}$ と縮合物を形成していると考えられる。 


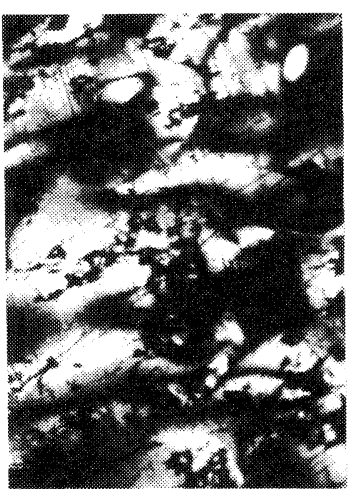

HCTP-100

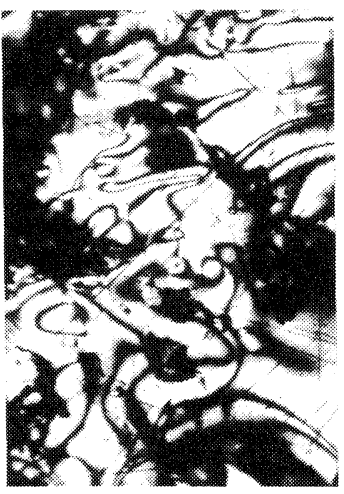

HCTP -80

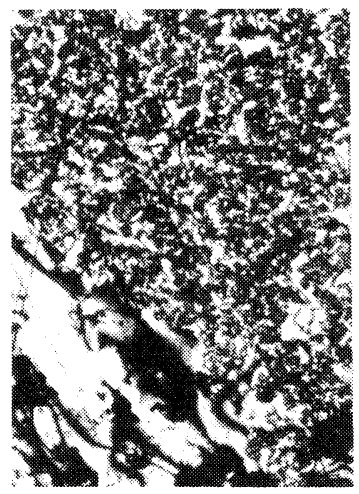

HCTP -70

$100 \mu \mathrm{m}$

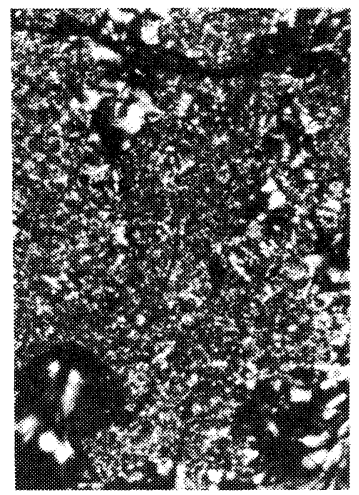

HCTP-60

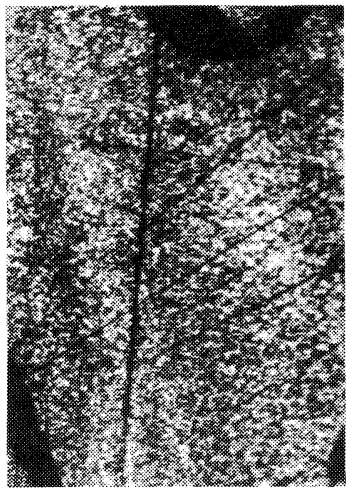

HCTP -50

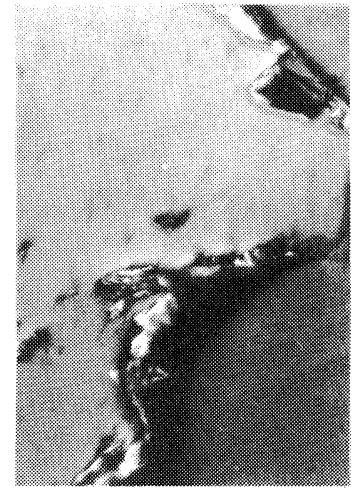

HCTP -40

Fig. 8 Polarized light microphotographs of CTP/AQ condensates heattreated at $440^{\circ} \mathrm{C}$ for $5 \mathrm{~h}$.

しかし生成した縮合物はほぼ同程度の高い炭素化収率を 示したととから, 縮合物の分子量はそれほど大きな相違 はないと推定される。

Fig.7では, AQ がさらに多くなると多少炭素化収率 の減少が見られる。てれは3.1で述べたように, CTP 系では $\mathrm{AQ}$ の添加割合が非常に多くなると縮合物の溶 剂不溶分量が幾分減少してくるととと何らかの関係があ るのかもしれない。

\section{4 炭素化物の組織}

CTP あるいは HCTP と AQ とから合成した縮合物 を $440^{\circ} \mathrm{C}$ で 5 時間炭素化したものについて, 光学的組織 を観察した。これらのうちで代表的な組織の顕微鏡写真
を Fig.8 执よび Fig.9亿，CTPあるいはHCTPと $\mathrm{AQ}$ との仕込比と異方性組織との関係を Table 3 亿ま とめた。乙の熱処理条件下では, 原料である CTP HCTP, 乙れらをポリリン酸処理したものは非常に異方 性のよく発達した流机構造が観察された。また $\mathrm{AQ}$ 亿対 するピッチの仕込比が比較的多い縮合物に扔いても, か なり流れ状組織が発達していた。しかしピッチの割合が 減少するにつれて次第に組織が複雑になり, 異方性の発 達した領域は限定されてくるとと屯に，一部ではモザイ ク状組織と共存してくる。CTP系ではピッチの仕込比 が70\%, HCTP系では50\%で完全なモザイク状組織を 呈するようになり,さらにピッチの比率が低くなると全 


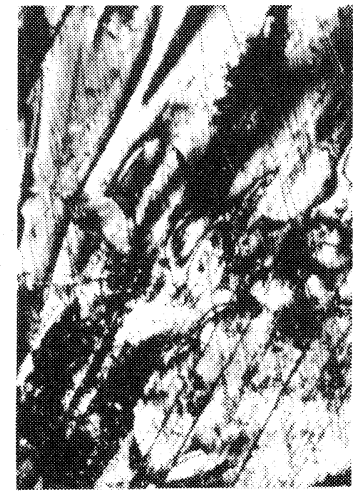

CTP-100

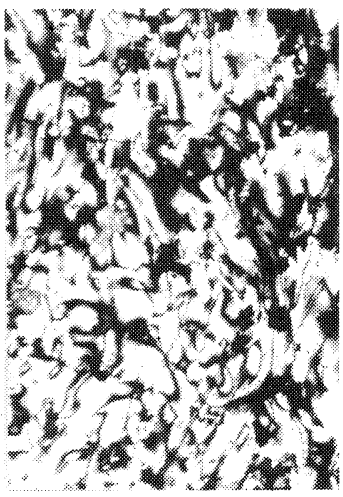

CTP-90

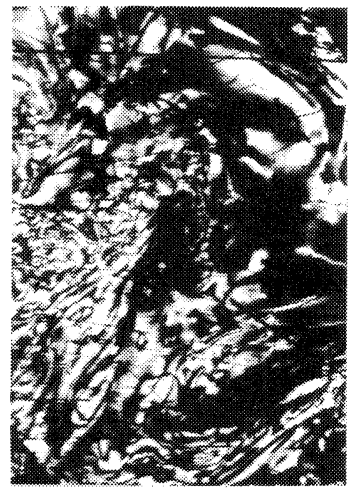

CTP-80

$100 \mu \mathrm{m}$

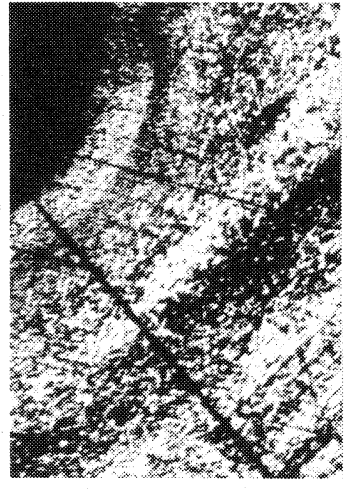

CTP-70

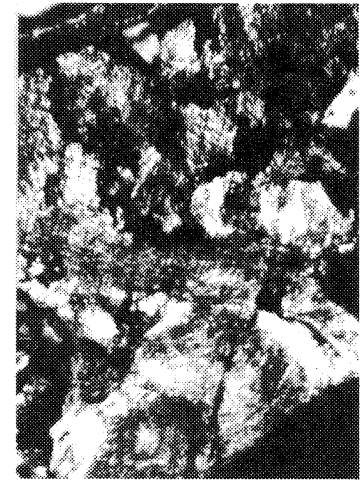

CTP-60

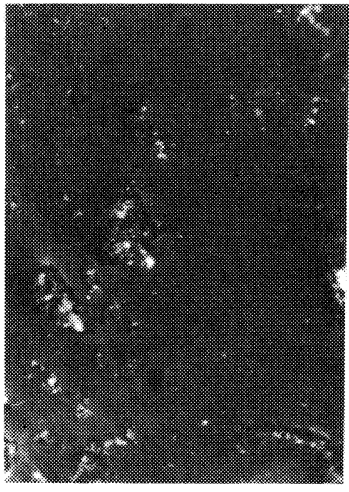

CTP-50

Fig. 9 Polarized light microphotographs of HCTP/AQ condensates heattreated at $440^{\circ} \mathrm{C}$ for $5 \mathrm{~h}$.

Table 3 Change in optical textures of heat-treated condensates with mixing ratio of pitch to anthraquinone (AQ).

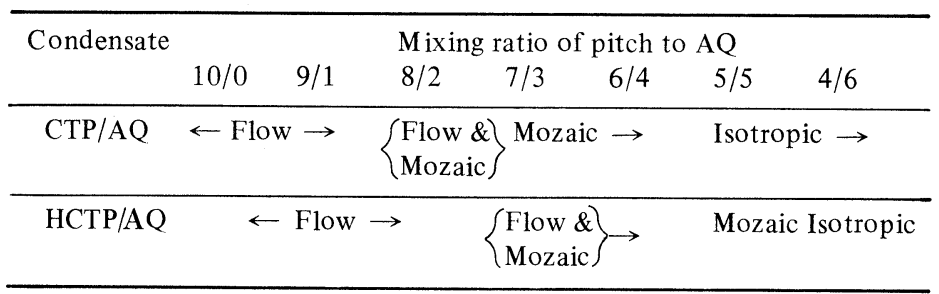




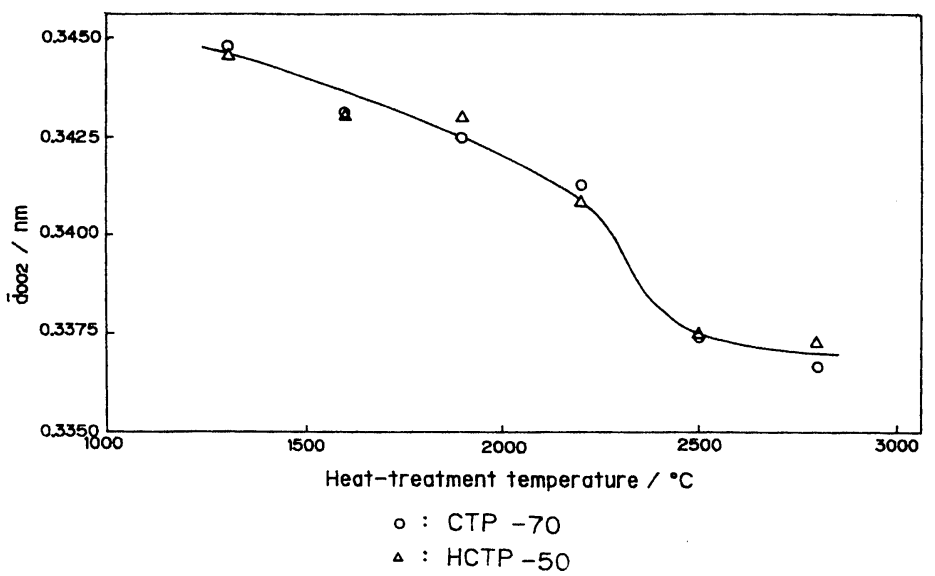

Fig. 10 Change in $\overline{\mathrm{d}}_{002}$ of carbon products from CTP-70 and HCTP- 50 with heat-treatment temperature.

体が等方性組織に変わる。完全にモザイク組織を示した 縮合物は上述の最高の炭素化収率を与えたそれらにほぼ 対応している。異方性組織の発達は系の軟化溶融性に密 接に関係していることから，ピッチがより多くの $\mathrm{AQ}$ と 縮合物を形成するにつれて分子の運動性が束縛されると 同時に，溶媒として作用する低分子成分が少なくなるた め, 分子配向が十分進まなくなり，流れ状からモザイク， 等方性組織へ之変わっていくあの之解釈される。炭素化 した組織の変化を, CTP あるいは HCTP と AQ とが同 じ仕込比で合成した縮合物について比較した場合 (Table 3), ピッチの水素化が異方性領域の発達をかなり促進 しているととがわかる。

炭素化収率が最高の値を示した CTP-70, HCTP-50 では，モザイク状組織を示したてとからも明らかなよう に, てれらの縮合物は粘度が高く, バインダーや炭素複 合材のマトリックスとして用いるのは困難と思われる。 しかし, 溶剂不溶分量が比較的少ないてとから(Fig. 1), 適当な溶剂を加えて粘度を低下させるなどの工夫をすれ ば，高炭素化収率のメリットを生かすてとができるかむ しれない。特に, HCTP と AQ の仕込比が 6/4 の縮合 物では, ピリジン不溶分量が約 $5 \%$ と非常に少ないにも かかわらず炭素化収率が65\% と高く, しかもその炭素化 物は異方性の発達がかなり見られた。それ故, てのよう な縮合物をバインダーやマトリックスとして利用する場 合，ピッチを水素化して扔くてとが肝要であろう。

\section{5 縮合物の黑鉛化}

Fig.10は代表的な縮合物として, 仕込比で CTP/AQ が 7/3, HCTP/AQ が 5/5の CTP-70, HCTP-50の 2 種類を選び, てれらを 1300 から $2800^{\circ} \mathrm{C}$ まで熱処理し,
その $\mathrm{X}$ 線回折の測定から求めた層面間隔の平均値, $\overline{\mathrm{d}}_{002}$ を熱処理温度に対してプロットしたものである。 $2200^{\circ} \mathrm{C}$ までは $0.34 \mathrm{~nm}$ 以上の值をとるが，2500から $2800^{\circ} \mathrm{C}$ になると $0.337 \mathrm{~nm}$ 亿低下し, 黒鉛化性はかなり よくなった。このような傾向は前報で報告したアントラ セン重合物の結果とよく似て扔り ${ }^{2)}$, 従来から知られて いるピッチなどの易黒鉛化性物質とはかなり異なった挙 動を示した。てのような縮合物やポリマーの黒鉛化挙動 については,さらに詳しい検討が必要である。

\section{4. 結言}

CTP あるいは HCTP と AQ の仕込比が種々異なる 縮合物をポリリン酸中で合成した。得られた生成物の溶 剂に対する溶解度の変化, 熱重量分析, 熱処理物の組織 などから縮合物の熱的特性を調べた。また，ピッチのモ デル化合物を用いて, AQ との反応機構も検討した。そ の結果, 次のことがわかった。

1) CTP/AQ の縮合物では, CTPに対する AQ の仕 込比が $7 / 3$ から $6 / 4$ の間で最高の炭素化収率(76\%) そ達し，その組織はモザイク状であった。

2） $\mathrm{HCTP} / \mathrm{AQ}$ の縮合物では, $\mathrm{AQ}$ との比率が $5 / 5$ で $\mathrm{CTP} / \mathrm{AQ}$ 系之同程度の炭素化収率抢よび異方性組織 を与えた。特に, ピッチの水素化処理は縮合物の溶剂 亿対する可溶化, 炭素化収率, 異方性組織の発達によ い影響を及ぼす。

3) $\mathrm{CTP} / \mathrm{AQ}$ では $7 / 3, \mathrm{HCTP} / \mathrm{AQ}$ では $5 / 5$ の仕込比 で合成した縮合物は, $2200^{\circ} \mathrm{C}$ までの熱処理では層面 間隔が広いが， $2500^{\circ} \mathrm{C}$ 以上に加熱するとかなり黒鉛 化性はよくなる。 


\section{謝 辞}

FD マススペクトルの測定にあたり，で協力いただい た公害資源研究所燃料資源部清水征生技官に感謝します。

\section{文献}

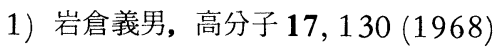

2) 山田能生, 古田 毅, 白石 稔, 炭素, 投稿中

3) I. Mochida, Y. Takeshita, Y. Korai, H. Fujitsu and K. Takahashi, Ind. Eng. Chem. Prod. Res. Dev. 1, 103 (1982)

4) E. Ota, S. Inoue, M. Horiguchi and S. Otani, Bull. Chem. Soc. Jpn. 52, 3400 (1979)
5) I. Mochida, K. Shimizu, Y. Korai, H. Otsuka and S. Fujiyama, Carbon 26, 843 (1988)

6) 岩崎 徹, 角南好彦, 杉本行廣, 炭素 1988[No. 134] 149

7) 木村脩七, 安田榮一, 安田公一, 田辺靖博, 川村 和郎, 稲垣道夫, 炭素 1986 [No. 125] 62

8) Y. Yamashita and K. Ouchi, Carbon 20, 41 (1979)

9) 林 隆之, 徳光隆雄, 染料之薬品 15,86 (1970)

10) 持田 熏, “炭素材の化学上工学” 朝倉書店 (1990) p. 164

11) 太田悦郎, “炭素素原料の有効利用IV” CPC研究 会編 (1986) p. 47

1991年炭素材料学会2月セミナーテキスト頒布のご案内

B5版 50 頁

1部 3,605円（送料, 消費税込）

主 題：地球環境と炭素材料

1. 炭素材の吸着特性と制御技術 堤 和男（豊橋技科大）

2. 活性コークスによる大気浄化技術 过 和比古（三井鉱山(侏)

3. 水処理用活性炭の現状亡今後の展開 大西寛二（三菱化成株）

主 題 : 炭素材料の高度利用
4. 炭素䋐維補強コンクリートの特性と 建築物への適用現況 秋浜繁幸（侏エフアールシー）

5. 自動車材料の現状之今後の展開 糀谷幸 (日本自動車研究所)

6. 航空宇宙の技術確信をねらった傾斜 機能材料開発

新野正之（航空宇宙技術研究所） 上村誠一（日本石油(株)

7. 炭素材料の超高温特性之評価技術 相馬 勲（大阪工業技術試験所）

ご希望の方は, 書名, 申込者名, 所属, 送付先住所, 電話番号を明記の上, 学会 事務局まで書面にてお申込下さい。折り返し現品に納品書・請求書を添え発送いた します。

炭素材料学会事務局 $\mathbf{T} 113$ 東京都文京区湯島2-16-13 斉藤ビル 